\title{
The Effect of Vegetation Community and Environment on Gyrinops versteegii Growth
}

\author{
Rawana $^{1,2^{*}}$, Suryo Hardiwinoto ${ }^{3}$, Budiadi $^{3}$, Sri Rahayu $^{3}$ \\ ${ }^{1}$ Graduated Program of Faculty of Forestry, Gadjah Mada University, Jl. Agro No.1 Bulaksumur, Yogyakarta, Indonesia 55281 \\ ${ }^{2}$ Faculty of Forestry, STIPER Agricultural University, Jl. Nangka II, Maguwoharjo, Depok, Sleman, Yogyakarta, Indonesia \\ 55282 \\ ${ }^{3}$ Departement of Silviculture, Faculty of Forestry, Gadjah Mada University, Jl. Agro No. 1 Bulaksumur, Yogyakarta, Indonesia \\ 552810
}

Received 31 November 2017 /Accepted 27 April 2018

\begin{abstract}
Although Gyrinops versteegii has been domesticated by local community in Sragen Regency, the environmental factors and species which have high compatibility with G. versteegii still have not known yet. The objectives of this research were 1) to know which one of those vegetation communities that gives the best the diameter and height growth of the domesticated $G$. versteegii, and 2) to know the environmental factors that influenced the growth of the diameter and height of the domesticated $G$. versteegii. Sampling was done systematically with a plot of size $20 \times 20 \mathrm{~m}$ for trees, $10 \times 10 \mathrm{~m}$ for poles, and $5 \times 5 \mathrm{~m}$ for saplings with a total of 28 plots. SPSS Program version 22 was used for cluster, one-way anova, correlation, and multiple regression analysis. The results showed that for achieving the best $G$. versteegii growth, the G. versteegii should be planted under the community group which was dominated by Paraserianthes falcataria, T. grandis, Gliricidia sepium, and Eugenia aquea. Environmental factors affecting diameter growth of $G$. verteegii were organic carbon of the soil and the vegetation density. Meanwhile the environmental factors affecting the height growth of $G$. versteegii were temperature, light intensity, relative light intensity, organic carbon, CN ratio, $P, M g$, air humidity, and clay content.
\end{abstract}

Keywords: Gyrinops versteegii, community group, growth, agarwood, environment

*Correspondence author, email: cahalasan@gmail.com

\section{Introduction}

Gyrinops verteegii (Gilg.) Domke is one of the agarwood-producing tree species that has high economic value (Turjaman 2011; Mega et al. 2012; Susilo et al. 2014). The Species is naturally distributed from the eastern islands of Indonesia, i.e. East Nusa Tenggara, Timor, Lombok, Sulawesi, to Papua New Guinea (Susilo et.al. 2014; Trimulyanigsih 2014). Meanwhile G. walla is distributed on the island of Sulawesi and Sri Lanka (Hadi et al. 2011; Mohamed 2016). The Gyrinops sp has dominated many structures of forest vegetation in the tropical rainforest, from dry to swamps with altitude of $0-1000 \mathrm{~m}$ above sea level (Akter et al. 2013; Susilo et al. 2014; Trimulyaningsih 2014). $G$. versteegii is found in a lowland primary forest with altitude of $0-800 \mathrm{~m}$ above sea level. On the Sumbawa Island it is found at an altitude of 400-800 m above sea level from Mount Doro Tambiung in West Sumbawa to Mount Doro Saboke East Sumbawa (Susilo et al. 2014).

The $G$. versteegii is one of the endangered species due to over exploitation, so it needs to be domesticated. Although the domesticated $G$. versteegii has been carried out in Java Island including in Sragen Regency, the growth of $G$. versteegii has not been measured yet. In the nature, the $G$. versteegii does not grow in monoculture system, but it grows in the mix cropping community. Because of its origin habitat that poly-culture, the planting of G. versteegii should be planted adjoining the other species which has highest compatibility with this species. The problem of the research is to find the best species which has highest compatibility with $G$. versteegii.

Naturally, the $G$. versteegii tree is grown in mixed stand communities. According to Trimulyaingsih (2014) naturally, the G. versteegii tree positively associates with Planchonella nitida, Erytrina orientalis, Arenga pinnata, Albizia procera, Syzygium polyanthum, Canarium littorale, Nephelium lappaceum, Lansium domesticum, Dracontomelon dao, Ficus rumphii, Baccaurea racemosa, and Gnetum gnemon. The G. versteegii tree which is categorized as a tolerant tree has the negative correlation with Theobrona cacao, Artocarpus heterphylus, and Toona sureni. In the stratification of the canopy, the G. versteegii tree crown is in the second stratum or co-dominant tree which receives sunlight from above the canopy cannot receive light from the side. This suggest that naturally $G$. versteegii requires lower light intensity with high air humidity (Susilo et al. 2014).

Since 1918 agarwood which was extracted in natural forest has exported to Saudi Arabia, Singapore, Arab Emirates, and other country in form of wood chips (Heyne 1950). In the period 2005-2008, the G. versteegii agarwood export quota had steadily increased from 5-25 tons year ${ }^{-1}$. 
Meanwhile in the period 2008-2013 there was no export quota for the $G$. versteegii agarwood. The ability for supplying the export target has been decrease from year to year. According to Association of Indonesian Agarwood Traders (ASGARIN), in the 2013 the $G$. versteegii agarwood export was 8 tons (Ratri 2013). The decreasing of the $G$. versteegii agarwood export has been caused by decreasing the natural $G$. versteegii population due to over cutting and the low of natural $G$. versteegii production. Along with the demand of agarwood products continues to increase, the natural tree felling cannot be inevitable. While cultivated, Gyrinops cannot yet be harvested to produce the agarwood. The impact of uncontrolled logging is a very significant a natural population decline of $G$. versteegii. Therefore the Government of Indonesia incorporated this species into CITES Appendix II to regulate and limit its trade (Turjaman 2011; Blanchette et al. 2011; Soenarno \&Komang 2011). The $G$. versteegii also has listed at Red list IUCN 2009 as the endangered species. In addition according to Government Regulation Number $7 / 1999$ and Regulation of Forestry Minister Number 447/Kpts-II/2003 also stated that the $G$. versteegii is protected species, so it prohibited for trading and cutting.

The domestication effort of $G$. versteegii has been done in Indonesia since 1990. Generally, seedling which had been taken from the nature and planted in the planting site such as home garden, garden, and protected forest. However the planting of $G$. versteegii has still not succeeded yet because the planting technique was still not appropriate method and the selection of planting site was still unsuitable for this species (Trimulyaningsih \& Yamada 2007). In Vietnam, the domestication of agarwood has been conducted since 2000 year, and planting was done by monoculture system with plantation system (Blanchete 2007). Furthermore, since 2000 ex-situ conservation of the $G$. versteegii has been conducted by the group community in Java Island with planting several seedling of the $G$. versteegii in their home garden. Because of surviving the planted $G$. versteegii, the local government conducts to domesticate the species in their region. The Sragen regency domesticated the $G$. versteegii in 2004 with mix forest, a little bit monoculture system.

According to Hardiwinoto (2015) in domesticating the species, the deep assessing and selecting site must initially be conducted before planting the species which will be domesticated. Naturally, the $G$. versteegii grows in the vegetation community composed many species which interrelationship each other, so it composes the specific vegetation community. Domestication, ex-situ conservation effort, requires selection of site which ecologically has special characteristics of soil, climate and vegetation communities. The selection of appropriate environmental factors can support not only for the growth of the diameter and height but also for the increase of agarwood which has quantitatively and qualitatively the best product. Moreover, grouping the vegetation which comprises composition and abundance of species also affects the $G$. versteegii growth. The research of the effect of a vegetation community for the growth of the diameter and height of the $G$. versteegii tree in Sragen Regency has not done yet. The objectives of this research were: (1) to know which one of those vegetation communities that gives the best the diameter and height growth of the domesticated $G$. versteegii, and (2) to know the environmental factors that influenced the growth of the diameter and height of the domesticated $G$. versteegii.

\section{Methods}

The research was conducted in the domesticated $G$. versteegii located in Bendungan village, Kedawung District, Sragen Regency, Central Java Province. This site is located in the area of state High School Agriculture of Kedawung (SMKN Pertanian Kedawung), while the management of $G$. versteegii plantation is controlled by Environmental Bureau of Sragen Regency. The research site was geographically located at $7^{\circ} 28^{\prime} 31.18 " \mathrm{~S}-7^{\circ} 28^{\prime} 40.95 \% \mathrm{~S}$ and $111^{\circ} 2^{\prime} 55.55^{\prime \prime} \mathrm{E}-111^{\circ} 3^{\prime} 8.50^{\prime \prime} \mathrm{E}$ with $116 \mathrm{~m}$ above sea level. The bio-physical conditions of the research site are the land slope of $2-3 \%$, grumosol soil type with rainfall of $2.123 \mathrm{~mm}_{\text {year }}{ }^{-1}$ and the amount of rainy days of 119 . This forest was planted in 2004 with the mixed forest pattern by the Forestry and Plantation Office of Sragen Regency, in forest area of 2 ha with $2 \times 3$ m planting spacing.

Seedling which was planted with height average of $40 \mathrm{~cm}$ height was taken from seed stand area in the West Nusa Tenggara Province via CV Alam Tropika. Planting hole was $30 \times 30 \times 30 \mathrm{~cm}$, and each of it was given with Bokashi fertilizer of $10 \mathrm{~kg}$ average. In the beginning of planting, watering was done every 2 days at the dry season using irrigation channel. Furthermore after the plantation achieved 3 years old, watering was conducted only in the extreme condition such a long dry season. Neither thinning activity nor maintaining pest and diseases were done because of the goodness of plantation health.

A quadratic method was used for taking sample with a plot which has size $20 \times 20 \mathrm{~m}$ for trees, $10 \times 10 \mathrm{~m}$ for poles, and $5 \times 5 \mathrm{~m}$ for saplings. The plots systematically designed with amount of 28 plots. The data was measured on April month until July in 2017. Taking of a soil sample was done at $0-30 \mathrm{~cm}$ in depth then it was analyzed at the soil laboratory. The parameter of soil analyses were $\mathrm{pH}$, soil moisture, cation exchange capacity (CEC), organic matter, C-organic, $\mathrm{C} \mathrm{N}$ ratio, $\mathrm{N}$ element, $\mathrm{P}$ element, $\mathrm{Mg}$ element, $\mathrm{Ca}$ element, and soil texture.

Hierarchical cluster analysis method Grouping of the vegetation community based on the abundance species in each plots depicted as a dendrogram. A cluster method used was the hierarchical cluster analysis with a squared Euclidean distance with computation of SPSS Program version 22 (Ludwig \& Reynold 1988; Everitt et al. 2011):

$$
S E D_{i k i}=\sum_{i=1}^{s}\left(x_{i j}-x_{i h}\right)^{2}
$$

note: $S E D_{j k}=$ squared Euclidean distance of the $j$ th plot to the $k$ th plot, $x_{i j}=$ the abundance of the $i$ th species in the $j$ th plot, $x_{i k}=$ the abundance of the $i$ th species in the $k$ th plot, Agglomeration method was selected for grouping plots.

The Map of the tree canopy was made by ArcGIS 10.2.1 software, and the photo was taken by Google Earth Pro.

Important Value Index (IVI) The role of each species in the community was based on the value of the density, frequency, and dominance (Causton, 1988). Important Value Index (IVI) was the sum of the relative density (RD), relative 
dominance $(\mathrm{RC})$ and relative frequency $(\mathrm{RF})$ calculated using the following formula (Kusmana 1997):

$$
\text { Density }(1))=\stackrel{\text { all number of individial species }}{\text { the total widih of plots }}
$$

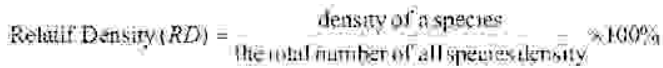

Dominance $(T)=\frac{\text { the total of basal area of a specazs }}{\text { the total widtl of plots }}$

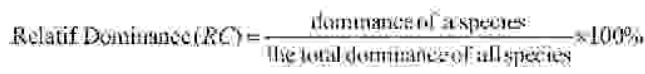

Fiequency $(F)=\frac{\text { The number of pol wheh is found a species }}{\text { The }}$

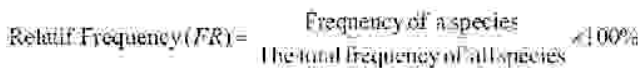

Important Value Indext $/ M)=R I I+R C^{\circ}+R F$

Correlation analysis method The correlation method was applied to know the correlation among variables i.e. air temperature, air humidity, light intensity, soil moisture 0.5 , soil $\mathrm{pH}$, soil organic matter, soil organic carbon, $\mathrm{N}, \mathrm{C} \mathrm{N}$ ratio, $\mathrm{P}, \mathrm{K}, \mathrm{Mg}, \mathrm{Ca}$, relative light intensity, cation exchange capacity, sand content, silt content, clay content, soil moisture 0.2, density, diameter, and height. The value of the correlation coefficient $(r)$ was calculated by the following formula (Shipley 2004; Orloci \& Kenkel 1987):

$$
r=\frac{m\left(\sum x y\right)-\left(\sum x \sum y\right)}{\sqrt{N \sum x^{2}-\left(\sum x\right)-\left[N \sum y^{2}-\left(\sum x\right)\right]}}
$$

note: $\mathrm{r}=$ correlation coefficient, $\mathrm{x}=$ variable $\mathrm{x}, \mathrm{y}=$ variable $\mathrm{y}$, $\mathrm{n}=$ number of population

The calculation of correlation analysis was used SPSS version 22 (IBM 2013).

Multiple linear regression analysis To know the effect of variables i.e. air temperature, air humidity, light intensity, soil moisture 0.5 , soil $\mathrm{pH}$, soil organic matter, soil organic carbon, $\mathrm{N}, \mathrm{C} \mathrm{N}$ ratio, $\mathrm{P}, \mathrm{K}, \mathrm{Mg}, \mathrm{Ca}$, relative light intensity, cation exchange capacity, sand content, silt content, clay content, soil moisture 0.2 , and density to growth of the G.versteegii diameter and height, was used a standardized multiple linear regression analysis by using SPSS Program version 22 for data computation. The equation model of multiple regressions used was as follow (Rawlings et al. 1989)

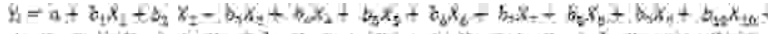

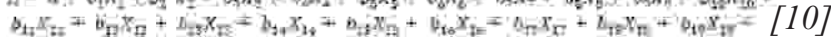

$4, x_{3} ; n$

note: $\mathrm{X}_{1}=$ air temperature $\left({ }^{\circ} \mathrm{C}\right), \mathrm{X}_{2}=$ air humidity $(\%), \mathrm{X}_{3}=$ light intensity (lux), $\mathrm{X}_{4}=$ soil moisture, $0.5 \mathrm{~mm}, \mathrm{X}_{5}=$ $\mathrm{pH}\left(\mathrm{H}_{2} \mathrm{O}\right)$ soil, $\mathrm{X}_{6}=$ soil organic matter $(\%), \mathrm{X}_{7}=$ soil organic carbon $(\%), \mathrm{X}_{8}=\mathrm{N}(\%) \mathrm{X}_{9}=\mathrm{C} \mathrm{N}$ ratio, $\mathrm{X}_{10}=\mathrm{P}$ $(\%), X_{11}=K\left(\right.$ me $\left.100 \mathrm{~g}^{-1}\right), X_{12}=\operatorname{Mg}\left(\right.$ me $\left.100 g^{-1}\right), X_{13}=$ cat ion exchange capacity (CEC), $\mathrm{X}_{14}=$ sand content (\%), $\mathrm{X}_{15}=$ dust content $(\%), \mathrm{X}_{16}=$ clay content $(\%), \mathrm{X}_{17}=$
Relative light intensity $(\%), \mathrm{X}_{18}=\mathrm{Ca}\left(\mathrm{me} 100 \mathrm{~g}^{-1}\right), \mathrm{X}_{19}=$ soil moisture $0.2 \mathrm{~mm}, \mathrm{X}_{20}=$ density (individual ha $\mathrm{h}^{-1}$ ), a, $\mathrm{b}_{1-20}=$ regression coefficient, $\mathrm{Yi}=$ dependent factor $\left(\mathrm{Y}_{1}=\right.$ diameter, $\mathrm{Y}_{2}=$ height $)$

The independent variables ( $\mathrm{X}$ variable) have different unit and scale, thus it is necessary to standardize the score of each variable. Standardization of variables was used the formula (Johnson 2014)

Standardized $x_{1}=\frac{x_{1}-\text { observed mean } x_{t}}{\text { observed standard deviasi } x_{1}}$

The variables were standardized using Equation [11] then analyzed using multiple regression analysis.

\section{Results and Discussion}

Grouping the vegetation community Based on the hierarchical cluster analysis the vegetation community based domesticated $G$. versteegii was clustered into 3 namely: group 1, group 2, and group 3. The group 1 composed of 14 species namely: Gyrinops versteegii (IVI $=177.87 \%$ ), T. grandis (IVI $=35.20 \%)$, Paraserianthes falcataria $(\mathrm{IVI}=17.28 \%)$, Manilkara zapota (IVI = 4.28\%), Dimocarpus longan $(\mathrm{IVI}=4.39 \%)$, Leucaena leucocephala $(\mathrm{IVI}=3.70 \%)$, Aleurites moluccana $(\mathrm{IVI}=3.78 \%)$, Eugenia aquea (IVI = 14.64), Mangifera indica $($ IVI $=3.33 \%)$, Artocarpus heterophyllus (IVI $=4.10 \%)$, Gliricidia sepium $(\mathrm{IVI}=23.38 \%)$, Cassia siamea $(\mathrm{IVI}=4.33 \%)$, and Eugenia malaccense (IVI $=3.69 \%)$. Because the $G$. versteegii, T. grandis, and G. sepium have the higher IVI value than the other species, the group 1 was called as group GyrinopsTectona-Gliricidia which was abbreviated as group G-TG.

Furthermore, Group 2 consisted of 4 species namely: Gyrinops versteegii (IVI $=213 \%), T$. grandis $(\mathrm{IVI}=$ $21.53 \%$ ), Paraserianthes falcataria (IVI $=46.32 \%$ ), and Gliricidia sepium (IVI = 18.34\%). The three species that had the highest IVI value namely $G$. versteegii, $P$. falcataria and T.grandis, so this group was called GyrinopsParaserianthes-Tectona group abbreviated as Group G-TP.

Moreover, group 3 composed of 11 species namely: Gyrinops versteegii $(130.55 \%)$, T. grandis (IVI $=74.21 \%)$, Manilkara zapota $(\mathrm{IVI}=10.54 \%)$, Dimocarpus longan $(\mathrm{IVI}$ $=9.23 \%)$, Leucaena leucocephala (IVI = 16.67\%), Swietenia macrophyla $($ IVI = 3.59), Leucaena glauca $(\mathrm{IVI}=$ 4.79\%), Aleurites moluccana (IVI =4.67\%), Eugenia aquea (19.05), Mangifera indica (IVI = 10.52), Artocarpus heterophyllus $(\mathrm{IVI}=3.94 \%)$, Cassia siamea $(\mathrm{IVI}=5.11 \%)$, Gliricidia sepium (IVI $=3.54 \%$ ) and Bauhinia purpurea $($ IVI $=3.47 \%)$. The three species that had the highest IVI value were $G$. versteegii, T. grandis and E. aquea. This group was called Gyrinops-Tectona-Eugenia group abbreviated as group G-TE, to characterize with other group.

Canopy cover of Gyrinops versteegii community was dominated by dominant tree (Figure 1a). The area of the GPT group was characterized by $P$. falcataria canopy which has light canopy, the G-TG group was attributed by $G$. sepium canopy, and the G-TE group was marked by E. aquea canopy (Figure 1b). The light achieving the forest floor is significantly affected by the characteristic of dominant tree canopy. The thicker of the dominant tree canopy was the smaller the light coming in forest stand. The light intensity under $P$. falcataria canopy in group GPT of 368.42 lux was 


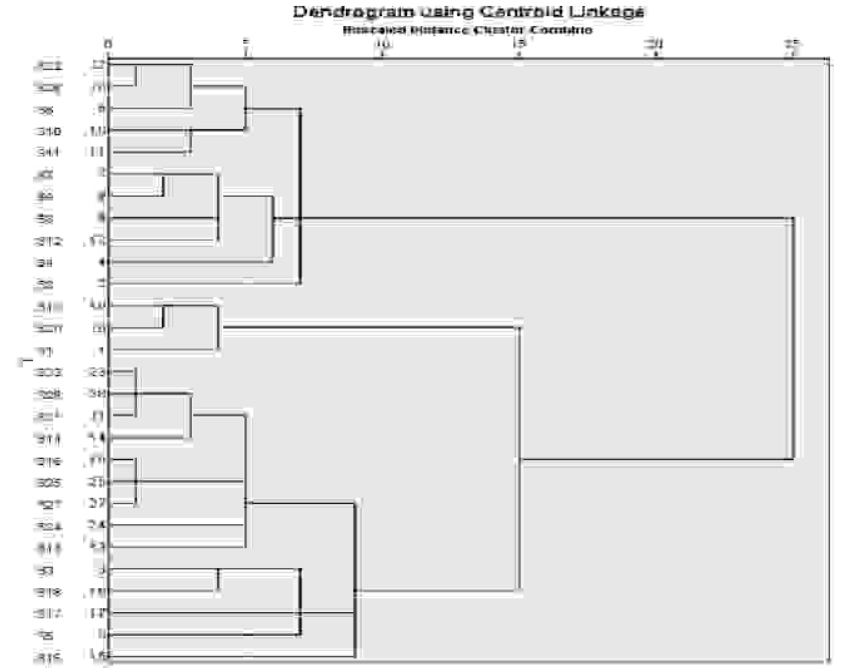

Figure 1 Adendrogram of vegetation community clustering using the species abundance.
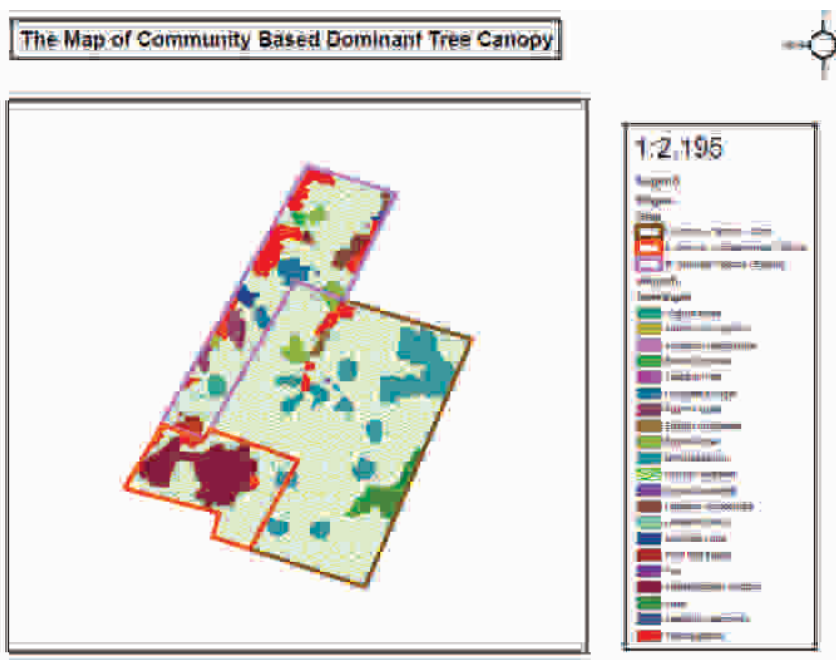

Figure $1 \mathrm{~b}$ The map of community based dominant tree canopy.

relatively higher than the light intensity under E.aquea canopy of 286.55 lux. The light intensity under $P$. falcataria canopy in group GPT of 368.42 lux was relatively higher than the light intensity under E. aquea canopy of 286.55 lux. The diameter growth of $G$. versteegii growing under $P$. falcararia canopy was relatively better than that growing under E.aquea canopy. Moreover the height growth of $G$. verteegii growing under $P$. falcataria canopy was significantly better than that growing under G.sepium canopy. The density of $G$. versteegii establishing under $P$. falcataria canopy was obviously better than that under $E$. aquea and G. sepium canopy. The bigger the grade density of $G$. versteegii was the higher the grade survival ability of $G$. versteegii in this site. Each species has specific canopy

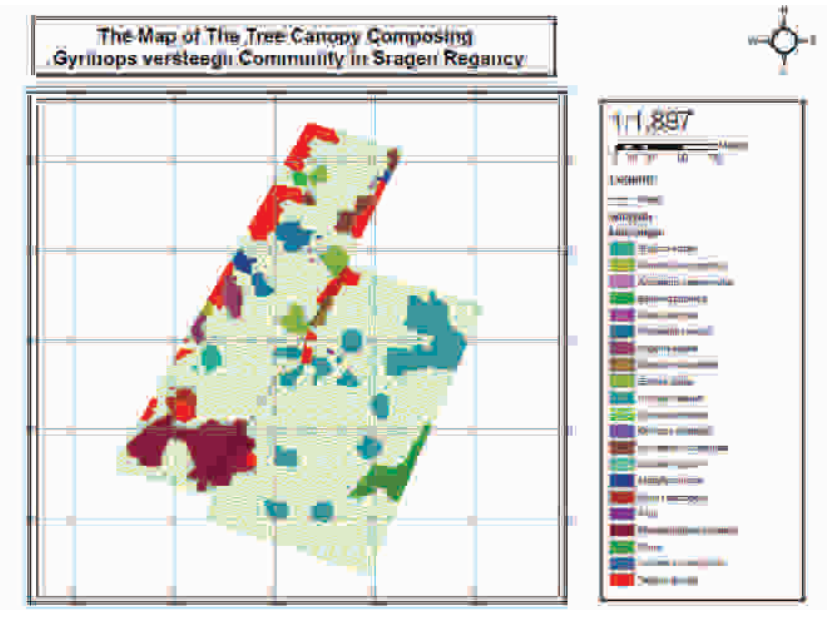

Figure 1a The map of the tree canopy composing $G$. versteegii community in Sragen Regency.

characteristic affecting its surrounding environment.

1 Diameter growth

Based on the multiple regression analysis of 20 variables in the three community groups, it was shown that the variable affecting the growth of the $G$. versteegii diameter was different at each community group. In the Gyrinops-Paraserianthes-Tectona group (G-PT), the variables which simultaneously (F test) affected the diameter of the stem were the organic carbon content and the clay content. Partially ( $\mathrm{T}$ test), the variable that significantly affected the growth of the $G$. versteegii tree was the soil organic carbon content. Furthermore in the Gyrinops-Tectona-Gliricidia group (G-TG), the variables which simultaneously (F test) affected the diameter of the $G$. verteegii tree were density, temperature, light intensity, relative light intensity, C N ratio, $\mathrm{P}$ element, $\mathrm{Mg}$ element, cation exchange capacity, sand content, and clay content. A variable which partially (T test) affected the growth of the G. versteegii tree diameter was the density.

Moreover the variables which simultaneously ( $\mathrm{F}$ test) had affected the growth of the $G$. versteegii tree diameter in the Gyrinops-Tectona-Eugenia group (G-TE) were the density, temperature, light intensity, relative light intensity, $\mathrm{P}$ content, $\mathrm{Mg}$ content and clay content. Partially, the variables that affected the growth of the tree diameter in three communities (G-PT, G-TG and G-TE) are organic carbon content and tree density. Based on Table 5 and Figure 2, the G-PT group gave the largest growth of the tree diameter $(13.134 \mathrm{~cm})$, followed by GTG Group $(12.165 \mathrm{~cm})$ and G-TE $(11.334 \mathrm{~cm})$. The G-PT community had the largest diameter due to the more suitably environmental condition for growth of the $G$. versteegii diameter. Two variables namely density of trees and the organic carbon content had significantly 
affected to growth of the tree diameter.

\subsection{Density}

The density of trees in the G-PT community had higher density average (784.34 individual ha ${ }^{-1}$ ) than the G-TG community (680.52 individual ha ${ }^{-1}$ ) and the G-TE (528.26 individual $\mathrm{ha}^{-1}$ ) (Table 5). The tree density affected strongly on the amount of the light intensity entering the vegetation canopy. The availability of light intensity is needed by plants in the process of photosynthesis which depends on the type of plant. An intolerant plant will require greater solar intensity than tolerant plants. The amount of light that enters the canopy of the plant is strongly influenced by climate (weather) when cloudy atmosphere of incoming light intensity is less than bright atmospheric conditions. Thickness of a canopy also affects the intensity that enters a forest canopy. The trees which have a thick canopy will get less light intensity than trees with a thin canopy. A high density will affect the ratio of light intensity which enters into a plant canopy.
The G-TE community had lower relative light intensity $(0.4 \%)$ than the G-TG $(0.9 \%)$ and the G-PT $(0.6 \%)$ communities (Table 5). Harper (1993) found that in Japan the percentage of full daylight reaching the ground between $0.1 \%$ (under Humulus japonicus species) to $37 \%$ (under Pinus densiflora stand). The light intensity which entered in the canopy of the G-PT community was 368.418 lux, and the light intensity which entered in the canopy of the G-TG and the G-TE communities were 286.549 lux and 232.32 lux. The growth of the $G$. versteegii tree diameter was quite good at light intensity ranging from 289.549 lux to 368.418 lux with the relative light intensity entering stands $0.566 \%-0.859 \%$. Even though the $G$. versteegii is a tolerant tree which can grow well under another crown tree, the species cannot grow well under the very heavy shading as those grown under the G-TE community. This data was suitable with research conducted by Trimulyaningsih (2014) that the G. versteegii tree grows naturally in tight density vegetation, with high air humidity (57-90\%), with an average temperature of 27.2

Table 1 Importance Value Index of the G-TG community group

\begin{tabular}{|c|c|c|c|c|}
\hline Species & $\mathrm{RD}(\%)$ & $\mathrm{RC}(\%)$ & RF $(\%)$ & IVI (\%) \\
\hline Gyrinops vesteegii & 36.84211 & 59.38109 & 81.65048 & 177.8737 \\
\hline Tectona grandis & 15.78947 & 12.53289 & 6.880658 & 35.20302 \\
\hline Gliricidia sepium & 15.78947 & 3.46293 & 4.128395 & 23.3808 \\
\hline Paraserianthes falcataria & 2.631579 & 14.1924 & 0.458711 & 17.28269 \\
\hline Eugenia aquea & 7.894736 & 4.452976 & 2.293553 & 14.64127 \\
\hline Dimocarpus longan & 2.631579 & 0.841349 & 0.917421 & 4.390349 \\
\hline Cassia siamea & 2.631579 & 1.240561 & 0.458711 & 4.33085 \\
\hline Manilkara zapota & 2.631579 & 1.192388 & 0.459811 & 4.283779 \\
\hline Artocarpus heterophyllus & 2.631579 & 1.009238 & 0.458711 & 4.099527 \\
\hline Aleurites moluccana & 2.631579 & 0.692353 & 0.458711 & 3.782642 \\
\hline Leucaena leucocephala & 2.631579 & 0.15712 & 0.917421 & 3.70612 \\
\hline Mangifera indica & 2.631579 & 0.24361 & 0.458711 & 3.333899 \\
\hline
\end{tabular}

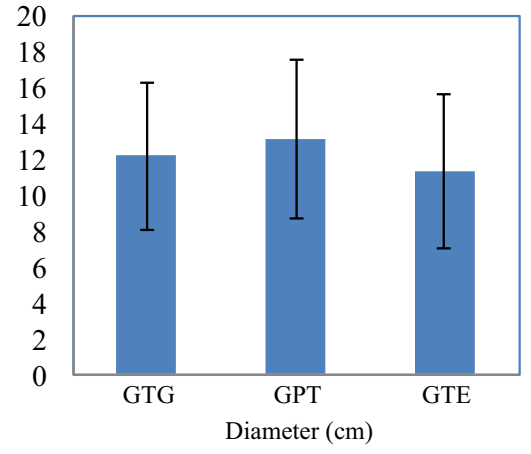

Series1 $12.16550463 \quad 13.13431791 \quad 11.33382126$

Figure 2 Graphic of average of diameter growth of $G$. versteegii tree.

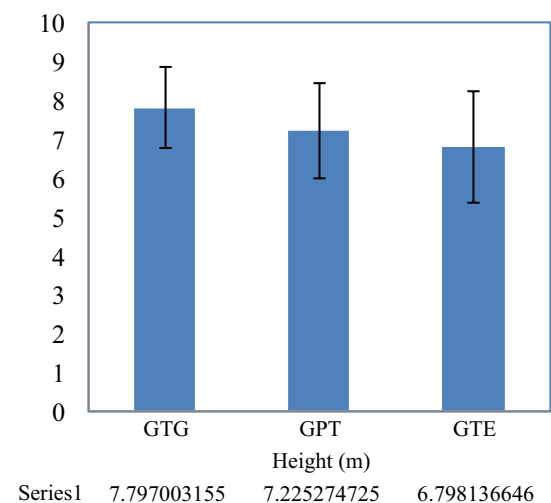

Figure 3 Graphic of average of height growth of G. versteegii tree. 
${ }^{\circ} \mathrm{C}$ or tolerance temperature $23{ }^{\circ} \mathrm{C}-32{ }^{\circ} \mathrm{C}$, and light intensity in the range of 126 lux -7175 lux.

A vegetation density was negatively correlated with a temperature. The higher the stand density will tend to be followed by the lower temperature in the forest. The average temperature of the G-PT community was 30.33 ${ }^{\circ} \mathrm{C}$ which was lower than the average temperature of the G-TG $\left(30.79^{\circ} \mathrm{C}\right)$ and the $\mathrm{G}-\mathrm{TG}\left(30.80^{\circ} \mathrm{C}\right)$ communities (Table 5). The higher tree density will tend to be followed by a decrease in temperature (Figure 4). The best temperature for growth of the G. versteegii diameter was $30.3^{\circ} \mathrm{C}$. The effect of the tree density on the tree diameter growth in the G-PT community group was expressed in the simple regression equation $(\mathrm{d}=-0.0116 \mathrm{k}+12.771)$ (Figure $4 \mathrm{~b}$ ), where $\mathrm{d}=$ diameter of tree and $\mathrm{k}=$ density. While the effect of the tree density on the tree diameter growth of the G-TG community is expressed by the equation $\mathrm{d}=-0.1075 \mathrm{k}+15.091$ (Figure 4a). The relationship of the tree density with the temperature average in the G-TE community is expressed by the equation $\mathrm{d}=0.0333 \mathrm{k}+30.091$ (Figure $4 \mathrm{c}$ ).

Both The G-PT and G-TG communities showed that the higher tree density tended to be followed by a decrease in a temperature. Tree density in the G-TG community had a higher rate of a temperature drop than the G-PT community. The value of a diameter change is depended on the coefficient value of a regression equation. Oppositely, the increasing of the tree density in the G-TE community had precisely caused increasing a temperature. This condition was caused by damage of a tree due to a death which attacked by a disease. In the three community groups, the air temperatures within the G-PT community gave the best tree diameter growth, as the temperature approached the natural habitat of the $G$. versteegii tree in average of $27.2{ }^{\circ} \mathrm{C}$ with a tolerance of $23^{\circ} \mathrm{C}-32^{\circ} \mathrm{C}$ (Trimulyaningsih 2014 ).

The average growth of $G$. versteegii growing under the G-TE community was larger than those which grown under both the G-TG and the G-PT communities. Therefore the dominant species, which had IVI value more than $10 \%$, that composed the G-TE community were T. grandis, Eugenia aquea, Leucaena leucochepala, Mangifera indica, and Manilkara zapota which those had very heavy crown. Because the light intensity that intercepted into the forest stands was very small, these species could not normally perform the photosynthesis process due to lacking of light intensity. The $G$. versteegii growing under those species with strong shading will be suppressed, so their growth will be abnormal.

From this condition, availability of light became limiting factor for the $G$. versteegii diameter growth. According to Lutz et al. (2012), large diameter trees dominate the structure, dynamic, and function of tropical ecosystem. They compose a large fraction of forest wood volume, biomass and carbon stocks, and modulate stand level leaf area, transpiration, and microclimate. Moreover they influence the rate and pattern of tree regeneration and forest succession and the greater structural complexity of large tree crown supporting

Table 2 Importance Value Index of the G-PT community group

\begin{tabular}{lrrrr}
\hline \multicolumn{1}{c}{ Species } & $\mathrm{RD}(\%)$ & $\mathrm{RC}(\%)$ & $\mathrm{RF}(\%)$ & $\mathrm{IVI}(\%)$ \\
\hline Gyrinops versteegii & 50 & 67.17729 & 96.62921 & 213.8065 \\
Paraserianthes falcataria & 16.66667 & 28.53106 & 1.123596 & 46.32132 \\
Tectona grandis & 16.66667 & 3.740523 & 1.123596 & 21.53079 \\
Gliricidia sepium & 16.66667 & 0.551128 & 1.123596 & 18.34139 \\
\hline
\end{tabular}

Table 3 Importance Value Index of the G-TE community group

\begin{tabular}{|c|c|c|c|c|}
\hline Species & $\mathrm{RD}(\%)$ & $\mathrm{RC}(\%)$ & $\mathrm{RF}(\%)$ & IVI(\%) \\
\hline Gyrinops versteegii & 28.16901 & 37.94057 & 64.44406 & 130.5536 \\
\hline Tectona grandis & 23.04738 & 31.904 & 19.25915 & 74.21052 \\
\hline Eugenia aquea & 7.682458 & 8.400456 & 2.962945 & 19.04586 \\
\hline Leucaena leucocephala & 10.24328 & 2.722573 & 3.703682 & 16.66953 \\
\hline Manilkara zapota & 2.560819 & 6.497198 & 1.481473 & 10.53949 \\
\hline Mangifera indica & 5.121639 & 3.919534 & 1.481473 & 10.52265 \\
\hline Dimocarpus longan & 5.121639 & 2.629077 & 1.481473 & 9.232188 \\
\hline Cassia siamea & 2.560819 & 1.804777 & 0.740736 & 5.106333 \\
\hline Leucaena glauca & 2.560819 & 1.484959 & 0.740736 & 4.786515 \\
\hline Aleurites moluccana & 2.560819 & 1.371321 & 0.740736 & 4.672877 \\
\hline Artocarpus heterophyllus & 2.560819 & 0.634478 & 0.740736 & 3.936034 \\
\hline Swietenia macrophylla & 2.560819 & 0.286215 & 0.740736 & 3.58777 \\
\hline Gliricidia sepium & 2.560819 & 0.237593 & 0.740736 & 3.539149 \\
\hline Bauhinia purpure & 2.560819 & 0.167257 & 0.740736 & 3.468813 \\
\hline
\end{tabular}


Table 4 The Pearson Correlation Coefficient (r) of A Environmental factor variable in Community Groups

\begin{tabular}{|c|c|c|c|c|c|c|}
\hline \multirow[b]{3}{*}{ Variables } & \multicolumn{6}{|c|}{ Community Groups } \\
\hline & \multicolumn{2}{|l|}{ G-TG } & \multicolumn{2}{|l|}{ G-PT } & \multicolumn{2}{|c|}{ G-TE } \\
\hline & Height & Diameter & Height & Diameter & Height & Diameter \\
\hline Density & $0.122 *$ & $-0.09 \mathrm{~ns}$ & $0.103 \mathrm{~ns}$ & $0.003 \mathrm{~ns}$ & $0.118 \mathrm{~ns}$ & $-0.042 \mathrm{~ns}$ \\
\hline Temperature $\left({ }^{\circ} \mathrm{C}\right)$ & $-0.044 \mathrm{~ns}$ & $-0.106 \mathrm{~ns}$ & $-0.562 * *$ & $-0.408 * *$ & $-0.484 * *$ & $-0.333 * *$ \\
\hline Air Humidity (\%) & $0.133^{*}$ & $-0.018 \mathrm{~ns}$ & $0.279^{* *}$ & $0.267^{*}$ & $-0.332 * *$ & $-0.316^{* *}$ \\
\hline Light intensity (lux) & $0.044 \mathrm{~ns}$ & $-0.062 \mathrm{~ns}$ & $-0.454 * *$ & $-0.374 * *$ & $-0.497 * *$ & $-0.346^{* *}$ \\
\hline IC Ratio(\%) & $0.155^{* *}$ & $0.079 \mathrm{~ns}$ & $-0.408 * *$ & $-0.348 * *$ & $-0.501 * *$ & $-0.349 * *$ \\
\hline Soil Moisture $0.5 \mathrm{~mm}$ & $-0.159 * *$ & $-0.103 n s$ & $-0.274 * *$ & $-0.136 \mathrm{~ns}$ & $-0.568 * *$ & $-0.214^{* *}$ \\
\hline Soil Moisture $0.2 \mathrm{~mm}$ & $-0.192 * *$ & $-0.147 * *$ & $-0.274 * *$ & $-0.136 \mathrm{~ns}$ & $-0.396 * *$ & $-0.266^{* *}$ \\
\hline $\mathrm{pH}$ & $-0.168 * *$ & $-0.127^{*}$ & $0.274^{* *}$ & $0.136 \mathrm{~ns}$ & $-0.279 * *$ & $-0.25^{* *}$ \\
\hline Organic Matter & $-0.198 * *$ & $-0.087 \mathrm{~ns}$ & $-0.274 * *$ & $-0.136 n s$ & $0.212 * *$ & $0.214 * *$ \\
\hline Organic carbon & $-0.198 * *$ & $-0.087 \mathrm{~ns}$ & $-0.274 * *$ & $-0.136 \mathrm{~ns}$ & $0.212 * *$ & $0.214 * *$ \\
\hline Nitrogen & $-0.19 * *$ & $-0.064 n s$ & $0.274 * *$ & $0.136 \mathrm{~ns}$ & $0.268 * *$ & $0.287^{* *}$ \\
\hline $\mathrm{C} / \mathrm{N}$ & $-0.131^{*}$ & $-0.067 \mathrm{~ns}$ & $-0.274 * *$ & $-0.136 n s$ & $0.241 * *$ & $0.181^{*}$ \\
\hline $\mathrm{P}$ & $-0.071 \mathrm{~ns}$ & $-0.054 n s$ & $-0.274 * *$ & $-0.136 n s$ & $0.128 \mathrm{~ns}$ & $0.191 *$ \\
\hline $\mathrm{K}$ & $0.175^{* *}$ & $0.15 \mathrm{~ns}$ & $0.001 \mathrm{~ns}$ & $0.001 \mathrm{~ns}$ & $-0.025 n s$ & $-0.128 \mathrm{~ns}$ \\
\hline $\mathrm{Ca}$ & $-0.109 n s$ & $-0.057 \mathrm{~ns}$ & $-0.274 * *$ & $-0.136 n s$ & $-0.201^{*}$ & $-0.162 *$ \\
\hline $\mathrm{Mg}$ & $0.259 * *$ & $0.126^{*}$ & $0.001 \mathrm{~ns}$ & $0.001 \mathrm{~ns}$ & $-0.151 \mathrm{~ns}$ & $-0.076 \mathrm{~ns}$ \\
\hline $\mathrm{CEC}$ & $0.091 \mathrm{~ns}$ & $0.061 \mathrm{~ns}$ & $-0.274 * *$ & $-0.136 n s$ & $0.428 * *$ & $0.227 * *$ \\
\hline Sand content & $0.08 \mathrm{~ns}$ & $-0.015 n s$ & $-0.274 * *$ & $0.136 \mathrm{~ns}$ & $0.151 \mathrm{~ns}$ & $0.024 \mathrm{~ns}$ \\
\hline Dust content & $0.003 \mathrm{~ns}$ & $0.087 \mathrm{~ns}$ & $-0.274 * *$ & $-0.136 n s$ & $0.323 * *$ & $0.303 * *$ \\
\hline Clay content & $-0.088 \mathrm{~ns}$ & $-0.106 \mathrm{~ns}$ & $-0.274 * *$ & $-0.136 \mathrm{~ns}$ & $-0.303^{* *}$ & $-0.226^{* *}$ \\
\hline
\end{tabular}

Ns non-significant $\mathrm{p}>0.05, *$ significant $\mathrm{p}<0.05$ and $* *$ very significant $\mathrm{p}<0.01$

habitat to obligate wild life species and to develop soil and to store water within the forest canopy.

\subsection{Organic Carbon (C-organic)}

The G-TG community group had the highest $\mathrm{C}$ organic content of $3.07 \%$, and then it followed by the GTE community of $2.184 \%$ and the G-PT community of $1.42 \%$ (Table 5 ). The amount of organic carbon content of the soil is strongly related to the amount of organic matter entering into the soil. The organic matter is strongly influenced by type of the vegetation community (Killham 2001). The G-TG community had more organic material than the G-TE and the G-PT communities. The soil organic carbon content was significantly associated with soil microorganisms, nutrient availability in the soil, and it was closely related to the cation exchange capacity (CEC). The soil lacking organic matter will result in chemical, physical, and biological degradation of soils that can damage soil aggregates and lead to soil solidification. Organic materials that have been decomposed by soil microorganisms will improve soil fertility. The rate of a decomposition process was strongly influenced by the value of a $\mathrm{C} N$ ratio index.

A value of the $\mathrm{C} \mathrm{N}$ ratio is relatively constant in the range of 8 to 15 with an average of 10 to 12 (Mesic et al. 2012; Ge et al. 2013). The $\mathrm{C} \mathrm{N}$ ratio is an indicator whether will be mineralized or even vice versa, the organic matter content in the soil will cause nitrogen mobilization into soil cell microorganisms. Soils that have a high $\mathrm{C} \mathrm{N}$ ratio value indicate that the organic matter content in the soil is quite high but the $\mathrm{N}$ content is low, so it causes the $\mathrm{N}$ element in the soil to be mobilized to the tissue of microorganisms. The high $\mathrm{C} \mathrm{N}$ ratio impact will cause the $\mathrm{N}$ content in the soil to decrease and the crops get nitrogen deficiency.

The G-PT community group had lower $\mathrm{C} \mathrm{N}$ ratio value (11.981) than the G-TE community group (C N ratio $=13.234)$ and the $\mathrm{G}-\mathrm{TG}$ community group $(\mathrm{C} \mathrm{N}$ ratio $=16.187)$. The $\mathrm{C} \mathrm{N}$ ratio value of the $\mathrm{G}-\mathrm{PT}$ community was categorized as normal because of within the range of $10: 1$ to $12: 1$ (Prasad \& Power 1997). A normal $\mathrm{C} \mathrm{N}$ ratio will ensure no $\mathrm{N}$ element which is mobilized by microorganisms, and nutrient availability in the soil will increase. The availability of Nitrogen element will rapidly increase the growth with the greater development in stems and leaves into dark green (Foth 1984). The value of the cation exchange capacity for the G-TG community land had lower score of 28.24 me 100 $\mathrm{g}^{-1}$ than the soil in the G-TE community of 28.07 me 100 $\mathrm{g}^{-1}$, and the soil in the G-PT community of 27.78 me 100 $\mathrm{g}^{-1}$ (Table 5). The high of the CEC value shows the increase of soil fertility. The CEC value of three communities (G-TG, G-PT, and G-TE) was categorized

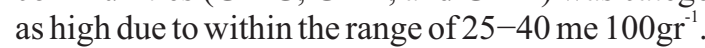

\subsection{P and $\mathrm{Mg}$ elements}

Two elements ( $\mathrm{P}$ and $\mathrm{Mg}$ ) simultaneously ( $\mathrm{F}$ test) had an effect on the growth of the $G$. versteegii tree diameter, but partially ( $\mathrm{T}$ test) had no effect on the growth of the G. versteegii diameter. The Phosphor (P) 


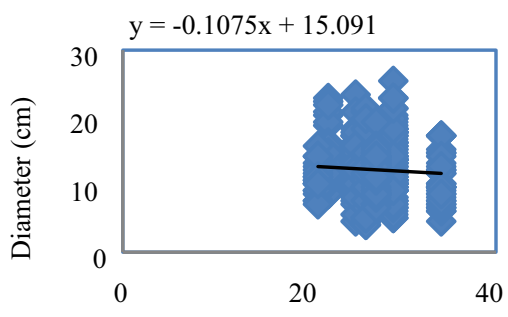

Density (ind $400 \mathrm{~m}^{-2}$ )

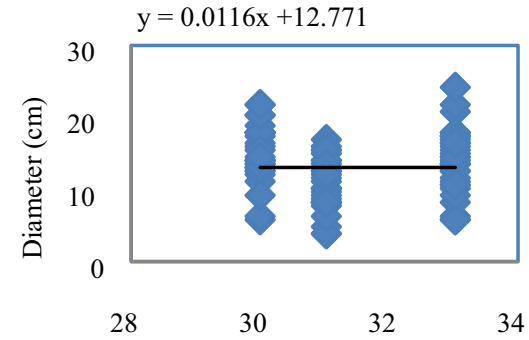

Density (ind $400 \mathrm{~m}^{-2}$ )

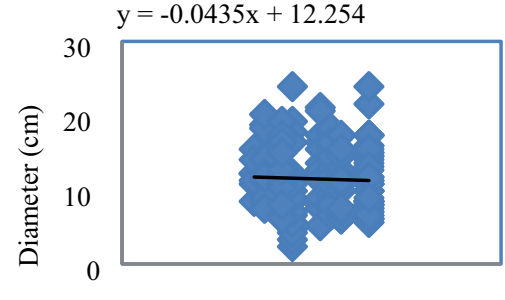

20

40

Density (ind $400 \mathrm{~m}^{-2}$ )

Figure 4 The effect of density to diameter growth of G.versteegii: (a) in G-TG Group (b) in G-PT Group, and (c) in G-TG Group.

element content in the G-PT community had higher value $(0.1 \%)$ than the G-TG community $(0.06 \%)$ and the G-TE community $(0.05 \%)$. Phosphor plays an important role in the biochemical activity of living cells due to the fuel/energy in the form of the adenosine triphosphate bond (ATP). The ATP conversion to Adenosine diphosphate (ADP) will produce the energy that living things use for metabolic activity. Plant tissue contains $0.3 \%$ phosphorus (Foth 1984). Phosphorus content in the three community groups was categorized as low because of less than normal conditions of $0.2-0.5 \%$. Therefore, GPT community had higher diameter growth because their phosphorus content was larger than those of the other communities.

The $\mathrm{Mg}$ element in the G-TG community had greater value $\left(3.248 \mathrm{me} 100 \mathrm{~g}^{-1}\right)$ than the G-TE community (3.24 me $\left.100 \mathrm{~g}^{-1}\right)$ and the G-PT community (3.21 me $\left.100 \mathrm{~g}^{-1}\right)$. A Mg element works for formation of a chlorophyll in leaves, improves the quality and quantity of production as co-factor of an enzyme, increases the soil $\mathrm{pH}$ and improves the soil structure due to the application of chemical fertilizers, and reduces the poisonous pollutant due to high $\mathrm{Al}$ and $\mathrm{Fe}$ content (Foth 1984) .All three community groups had $\mathrm{Mg}$ content with high category because it was in the range of $2.1-8 \mathrm{me}^{100 \mathrm{~g}^{-1}}$ (Yamani 2010). The supply of Mg element in three community groups was sufficient so that the $\mathrm{Mg}$ element is not as a growth constraint.

\section{Height growth}

A height which is measured from the top of the soil to the highest canopy perpendicularly is one of the parameters used as an indicator to measure tree growth. The G.versteegii tree growing in the G-TG community had higher average growth rate $(7.797 \mathrm{~m})$ than the $\mathrm{G}$ versteegii trees growing in the G-PT community $(7.225 \mathrm{~m})$ and the G-TE community $(6.798 \mathrm{~m})$ (Figure 3). Based on the result of the multiple regression analysis on 20 independent variables, the result obtained the variables that affect simultaneously ( $\mathrm{F}$ test) on the growth of G. versteegii tree diameter in the G-TG community were temperature, humidity, light intensity, IC ratio, $\mathrm{C} \mathrm{N}$ ratio, $\mathrm{P}$ element content, $\mathrm{Mg}$ element content, Cation Exchange Capacity, clay content, and sand content. Partially (T test) the variables affected the growth of the tree height in group G-TG were air humidity and clay content. Simultaneously (F test) the variables had effected on the growth of tree height in GPT group were organic Carbon content and clay content. Meanwhile the variable which partially (T test) affected the growth of tree height in G-PT group was the organic carbon content of soil. Furthermore the variables which simultaneously (F test) affected the growth of tree height in group G-TE were temperature, relative light intensity, temperature, $\mathrm{P}$ content, light intensity, $\mathrm{Mg}$, density, and humidity. Variables, that partially (T test) effected on tree height growth in group G-TE were temperature, light intensity, Mg element content.

Variables which partially affected the growth of the G. versteegii tree height in the three community groups were light intensity, temperature, humidity, $\mathrm{Mg}$ element, organic carbon, and clay content.

\subsection{Light intensity, temperature, and humidity}

The G-TG community group had lower light intensity (286.548 lux) than the G-PT community group (368.418 lux) and the G-TE group (1112.91 lux) (Table 5). Although the G. verteegii which grew in the G-TG community got the lowest light intensity, it grew better than two other communities (G-PT and G-TE). This was in accordance with research conducted by Trimulyaningsih (2014) where the growth of $G$. versteegii in nature ranges from $126-7.175$ lux.

The average of air temperature in the G-TE and the $\mathrm{G}-\mathrm{TE}$ communities was $30.8^{\circ} \mathrm{C}$. It was higher than the average of temperature in the G-PT community of $30.3^{\circ} \mathrm{C}$. Three communities (G-TG, G-PT, and G-TE) had appropriate air temperature for $G$. versteegii tree growth. According to research conducted by Trimulyaningsih (2014) that in nature G. versteegii grows well at $21.8-32^{\circ} \mathrm{C}$ tolerant temperature. The temperature positively correlated with the light intensity. Simultaneous increase of light intensity would be followed by an increase in temperature in all three community groups.

The level of light intensity influence in each community showed different effects, and the increase of light intensity to the G-TG group gave more influence in temperature increase than to the other two communities. The relationship of temperature and light intensity in the G-TG group is formulated by the equation $\mathrm{T}=0.0001 \mathrm{c}+$ 30.754 (Figure 8a), where $\mathrm{T}$ is the temperature and $\mathrm{c}$ is 
the light intensity. While the relationship between temperature and light intensity in G-PT group is formulated with the formula $\mathrm{T}=0.0007 \mathrm{c}+30.061$ (Figure 8b). Furthermore, the relationship of temperature and light intensity in group G-TE is formulated with equation $\mathrm{T}=4 \mathrm{E}-05 \mathrm{c}+30.751$ (Figure $8 \mathrm{c}$ ).

The air humidity of $67.0 \%$ could affect for achieving the $G$. versteegii diameter growth $7.8 \mathrm{~m}$, followed by air humidity $66.3 \%$ with high growth of 7.2 $\mathrm{m}$, and then air humidity $67.4 \%$ with high growth reaching $7.6 \mathrm{~m}$ (Figure 5). This is in accordance with research conducted by Trimulyaningsih that $G$. versteegii tree can grow well on the air humidity tolerance of 57-90\%. Air humidity had a tendency to negatively correlate with air temperature. In the G-TG and G-PT communities indicate that a temperature increase would be followed simultaneously with a decrease of air humidity. The relationship between temperature and air humidity in the G-TG group is formulated by the mathematical formula $\mathrm{H}=-1.394 \mathrm{~T}+109.94$ (Figure 7a) where $\mathrm{H}$ is air humidity and $\mathrm{T}$ is air temperature. The relationship of temperature and humidity in G-PT group is formulated with the formula $\mathrm{H}=-1.2097 \mathrm{~T}+103.02$ (Figure $7 \mathrm{~b}$ ). In other hand the G-TE community group had positively correlated between air temperature and air humidity. The increase of air temperature would be followed by the increase of moisture, and this condition was influenced by the structure of vegetation constituents. Air humidity affects tree growth (Jihau et al. 2015; Pet. 2012). The G. versteegii growth required air humidity of $66.349 \%$. The $G$. versteegii grows well in areas that have moderate humidity (Soenarno 2011).

The $G$. versteegii crown in the GSL community group was structured by 2 strata. The first stratum was structured by $P$. falcataria and $T$. grandis, and the second stratum was structured by the $G$. versteegii. The $P$. falcataria and $T$. grandis crown had reduced the light intensity entering into the canopy, so it caused lowering the temperature and increasing the air humidity in the forest stand. The light intensity greatly affects tree growth (Hart, 1988; Ali, 2013; Xiu-ru et al. 2013). The $G$. versteegii tree diameter grew well at intensity 361.67 lux because of tolerant type. A tolerant tree in its growth requires the shading (Soenarno 2011; Abrari et al. 2012; Mori \& Takeda 2003).

\subsection{Organic Carbon (C organic)}

The soil organic carbon significantly influenced the height growth of The G. versteegii tree. A high organic carbon content affected the availability of nutrients for plants to perform metabolic processes. Carbon and Nitrogen elements are the main elements used for the process of photosynthesis. If the soil has high content of $\mathrm{C}$-organic with low content of Nitrogen, the Nitrogen in the soil will be mobilized to microorganism. The threshold which the net mineralization of $\mathrm{N}$ element

Table 5 The result of laboratory analysis and field measurement of environmental factors in three type of a community group.

\begin{tabular}{|c|c|c|c|}
\hline Items & $\begin{array}{c}\text { G-TG Group } \\
(\text { Mean } \pm \text { SD) }\end{array}$ & $\begin{array}{l}\text { G-PT Group } \\
\text { (Mean } \pm \text { SD) }\end{array}$ & $\begin{array}{l}\text { G-TE Group } \\
\text { (Mean } \pm \text { SD) }\end{array}$ \\
\hline Average of the height (m) & $7.80 \pm 1.040 \mathrm{c}$ & $7.23 \pm 1.226 \mathrm{~b}$ & $6.84 \pm 1.425 \mathrm{a}$ \\
\hline Average of the diameter $(\mathrm{cm})$ & $12.17 \pm 4.088 \mathrm{a}$ & $13.13 \pm 4.386 b$ & $11.33 \pm 4.282 \mathrm{a}$ \\
\hline Species density (ind. ha ${ }^{-1}$ ) & $680.52 \pm 85.15$ & $784.34 \pm 31.76$ & $528.26 \pm 102.74$ \\
\hline Air temperature $\left({ }^{\circ} \mathrm{C}\right)$ & $30.79 \pm 0.492 \mathrm{a}$ & $30.33 \pm 0.187 b$ & $30.80 \pm 0.822 \mathrm{a}$ \\
\hline Air humidity (\%) & $67.00 \pm 1.721 \mathrm{~b}$ & $66.33 \pm 0.472 \mathrm{a}$ & $67.44 \pm 1.336 \mathrm{c}$ \\
\hline Light Intensity (lux) & $286.55 \pm 143.027 \mathrm{a}$ & $368.42 \pm 206.721 \mathrm{a}$ & $1112.91 \pm 2064.09 \mathrm{~b}$ \\
\hline Relative light intensity (\%) & $0.86 \pm 0.932 \mathrm{a}$ & $0.57 \pm 0.296 \mathrm{a}$ & $1.83 \pm 3.257 \mathrm{~b}$ \\
\hline Soil Moisture $0,5 \mathrm{~mm}$ & $5.20 \pm 0.828 \mathrm{a}$ & $5.72 \pm 1.346 \mathrm{c}$ & $5.50 \pm 0.956 \mathrm{~b}$ \\
\hline Soil moisture $0,2 \mathrm{~mm}$ & $8.95 \pm 0.824 \mathrm{a}$ & $9.85 \pm 1.217 \mathrm{~b}$ & $9.74 \pm 1.647 \mathrm{~b}$ \\
\hline Soil $\mathrm{pH}\left(\mathrm{H}_{2} 0\right)$ & $6.65 \pm 0.070 \mathrm{~b}$ & $6.56 \pm 0.034 \mathrm{a}$ & $6.67 \pm 0.056 \mathrm{c}$ \\
\hline Organic matter (\%) & $5.29 \pm 2.719 \mathrm{c}$ & $2.45 \pm 0.408 \mathrm{a}$ & $3.77 \pm 2.389 \mathrm{~b}$ \\
\hline Organic carbon $(\%)$ & $3.07 \pm 1.577 \mathrm{c}$ & $1.42 \pm 0.237 \mathrm{a}$ & $2.18 \pm 1.386 \mathrm{~b}$ \\
\hline N (\%) & $0.17 \pm 0.036 \mathrm{c}$ & $0.12 \pm 0.012 \mathrm{a}$ & $0.15 \pm 0.037 \mathrm{~b}$ \\
\hline $\mathrm{C} \mathrm{N}$ ratio & $16.18 \pm 5.613 \mathrm{c}$ & $11.98 \pm 2.922 \mathrm{a}$ & $13.23 \pm 5.242 b$ \\
\hline $\mathrm{P}(\%)$ & $0.06 \pm 0.015 \mathrm{~b}$ & $0.10 \pm 0.021 \mathrm{c}$ & $0.06 \pm 0.012 \mathrm{a}$ \\
\hline $\mathrm{K}\left(\mathrm{me} 100 \mathrm{gr}^{-1}\right)$ & $0.44 \pm 0.034 \mathrm{~b}$ & $0.41 \pm 0.000 \mathrm{a}$ & $0.45 \pm 0.029 \mathrm{c}$ \\
\hline $\mathrm{Ca}\left(\right.$ me $\left.100 \mathrm{gr}^{-1}\right)$ & $7.10 \pm 0.081 \mathrm{~b}$ & $7.01 \pm 0.101 \mathrm{a}$ & $7.11 \pm 0.130 \mathrm{~b}$ \\
\hline $\mathrm{Mg}\left(\mathrm{me} 100 \mathrm{gr}^{-1}\right)$ & $3.25 \pm 0.071 \mathrm{~b}$ & $3.21 \pm 0.000 \mathrm{a}$ & $3.24 \pm 0.122 \mathrm{~b}$ \\
\hline CEC & $28.34 \pm 0.619 \mathrm{c}$ & $27.78 \pm 0.437 \mathrm{a}$ & $28.07 \pm 0.963 b$ \\
\hline Sand content (\%) & $25.70 \pm 2.935 b$ & $26.76 \pm 2.401 \mathrm{c}$ & $24.17 \pm 1.906 \mathrm{a}$ \\
\hline Dust content (\%) & $33.93 \pm 3.938 \mathrm{a}$ & $35.30 \pm 0.960 \mathrm{~b}$ & $34.10 \pm 2.483 \mathrm{a}$ \\
\hline Clay content & $40.37 \pm 2.780 \mathrm{~b}$ & $37.95 \pm 1.440 \mathrm{a}$ & $41.73 \pm 3.537 \mathrm{c}$ \\
\hline
\end{tabular}

The same letter behind the numbers shows no significant based on Duncan $\alpha=0.05$ 
equal to net mobilization of $\mathrm{N}$ element occurs on the value of $\mathrm{C} \mathrm{N}$ ratio equal 20:1 (Killham 2001). If the $\mathrm{C} \mathrm{N}$ ratio value is above the threshold ( $\mathrm{C} \mathrm{N}$ ratio $>20)$, there will be mobilization of soil Nitrogen to the microorganism. In other hand if the $\mathrm{C} \mathrm{N}$ ratio value is brought to the threshold $(\mathrm{C} \mathrm{N}$ ratio $>20)$, there will be nitrogen mineralization meaning that the soil gets $\mathrm{N}$ element from the decomposition process done by microorganisms. The $\mathrm{C} \mathrm{N}$ ratio value is negatively correlated with the availability of Nitrogen in soil. The lower of the $\mathrm{C} N$ ratio value in the soil is the greater the availability of $\mathrm{N}$ in the soil (Foth 1984). Three communities (G-TG, G-PT, and $\mathrm{G}-\mathrm{TE}$ ) had the $\mathrm{C} \mathrm{N}$ ratio value under the threshold so that $\mathrm{C}$ organic could be an additional nutrient for plants. In the G-PT community group, C-organic did not only significantly influence the growth of tree height but also had a significant effect on the growth of tree diameter $G$ versteegii.

\subsection{Clay content}

The percentage of clay content contributed significantly to the growth of the G. versteegii tree height. Based on the correlation analysis of the height growth of the $G$. versteegii in the three (G-TG, G-PT and G-TE) communities showed that the percentage of clay content was negatively correlated with the growth of tree diameter. The percentage of clay content in the G-TE community group with value $41.726 \%$ was higher than the G-TG community with value $40.369 \%$ and the G-PT community with value $38.6 \%$. In the other hand the average growth of the tree height in the G-TE group $(6.798 \mathrm{~m})$ was lower than two other communities (Table 5). The height growth of the G. versteegii in the G-TG community was $7.797 \mathrm{~m}$ which was the best growth because the soil was fertile which was characterized by the percentage of clay content of $40.369 \%$. The effect of clay content to the height growth in each community was different. The influence of clay content response to the tree height in G-PT group was formulated with linear equation $\mathrm{t}=-0.2328 \mathrm{x}+16.06$ (Figure $6 \mathrm{~b}$ ), where $\mathrm{t}=$ height of tree, $x=$ percentage of soil clay content. The influence of clay soil percentage to the tree height in GTG group was formulated with the equation $t=-0.033 \mathrm{x}+$ 9.1276 (Figure 6a). The influence of clay soil percentage in G-TE group is formulated with the equation $\mathrm{t}=$ $0.1107 \mathrm{x}+11.419$ ( Figure $6 \mathrm{c}$ ).

The clay texture soil gave the height growth of $\mathrm{G}$. versteegii trees larger than the sandish and dustish texture soil. Clay texture soil has the ability to provide more nutrients and water than the texture of the sand (Qamaruz-Zaman \& Schumann 2006; Blevins et al. 2005; Jones \& Jr 2012).

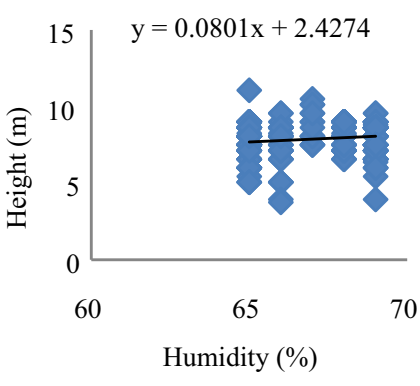

(a)

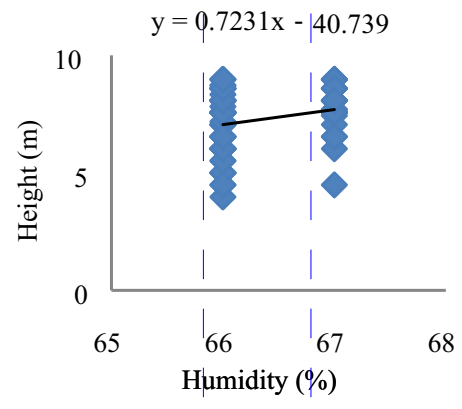

(b)

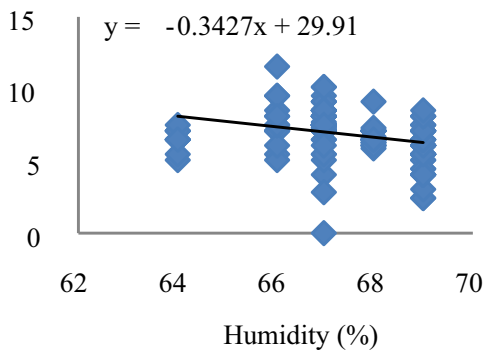

(c)

Figure 5 The effect of air humidity to height growth of G.versteegii tree: (a) in G-TG Group (b) in G-PT Group, and (c) in G-TE

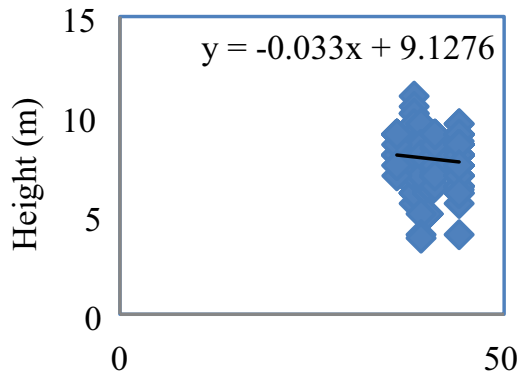

Clay content $(\%)$

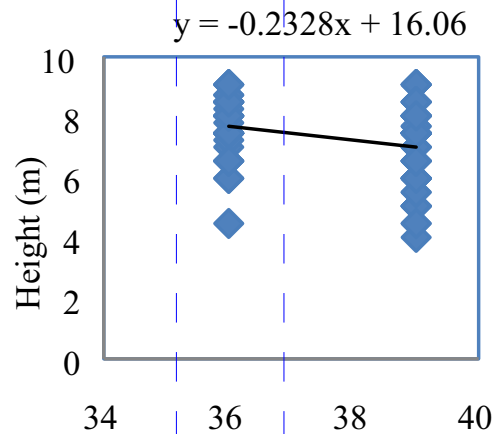

Clay content $(\%)$

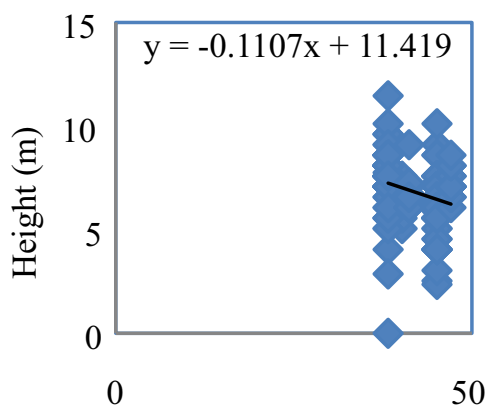

Clay content $(\%)$

(a)

(b)

Figure 6 The effect of clay content to height growth of G. versteegii tree: (a) in G-TG Group (b) in G-PT Group, and (c) in G-TE Group. 

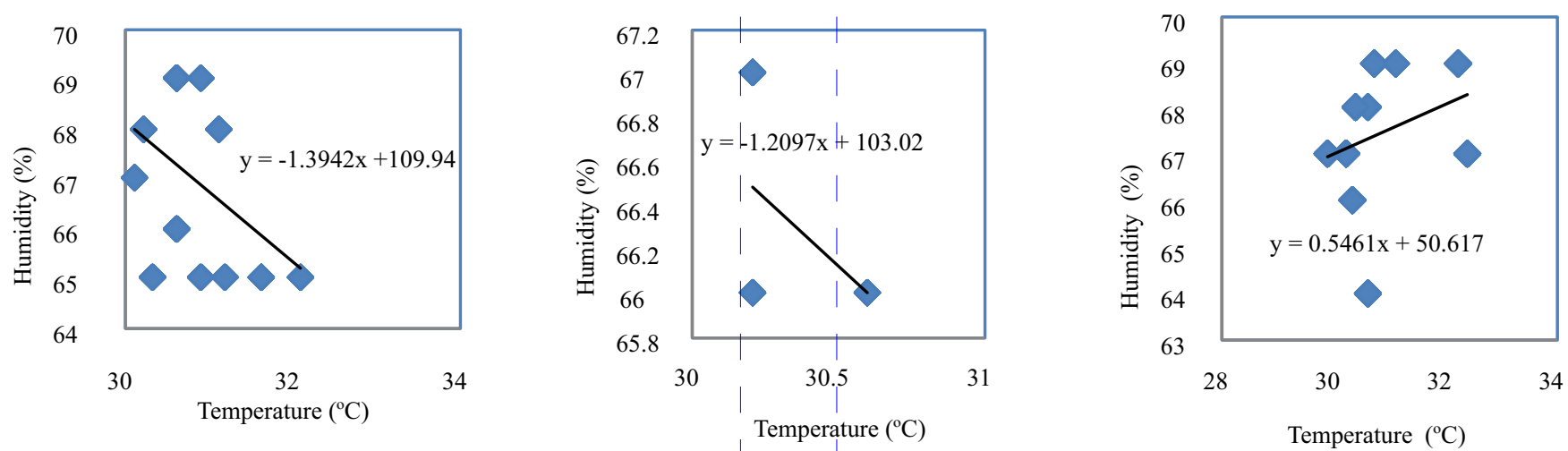

Figure 7 The effect of temperature to humidity (a) in G-TG Group (b) in G-PT Group, and (c) in G-TE Group.

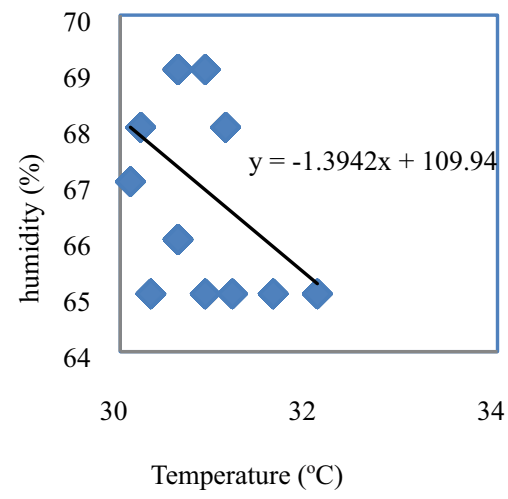

(a)

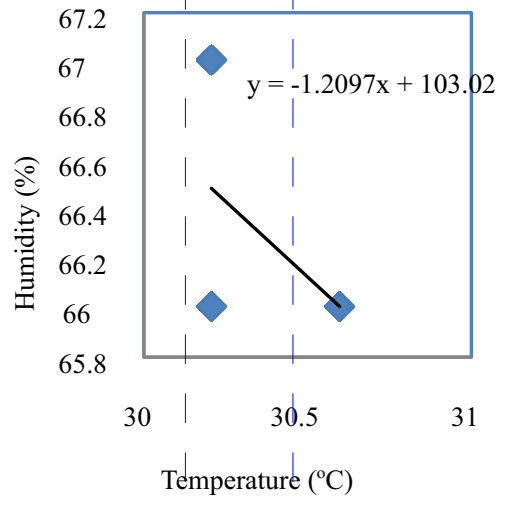

(b)

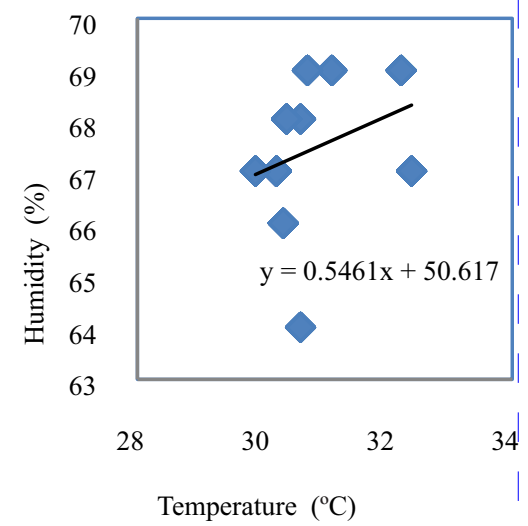

(c)

Figure 8 The effect of light intensity to temperature (a) in G-TG Group (b) in G-PT Group, and (c) in G-TE Group.

\section{Conclusion}

For achieving the best $G$. versteegii diameter growth, it should be planted under the G. versteegii-P. falcataria-T. grandis community which was dominated by Paraserianthes falcataria, T. grandis and Gliricidia sepium. Furthermore the highest $G$. versteegii growth will be achieved if those species were planted under the G. versteegii-T. grandis-G. sepium community which was dominated by Paraserianthes falcataria, T. grandis, Gliricidia sepium, and Eugenia aquea. Environmental factors affecting diameter growth of $G$. verteegii were organic carbon of the soil and the tree density. Meanwhile the environmental factors affecting the height growth of $G$. versteegii were temperature, light intensity, relative light intensity, organic carbon, $\mathrm{C} \mathrm{N}$ ratio, $\mathrm{P}$, $\mathrm{Mg}$, air humidity, and clay content.

\section{Acknowledgement}

The Authors gratefully thank to the Ministry of Research, Technology and Higher Education of The Republic of Indonesia funding this research. High appreciation is also extended to The Forestry and Plantation Agency and Environmental Bureau of Sragen Regency giving permission the research site.

\section{References}

Akter S, Islam T, Zulkefeli M, Khan SI. 2013. Agarwood production a multidiciplinary field to be explored in Bangladesh. International Journal of Pharmaceutical and Life Science 2(1):22-32.

Ali M. 2013. Climate Change Impact on Plant Biomass Growth. 1st edition. London: Springer.

Blanchette RA. 2007. Successful Production of Cultivated Agarwood: A New Economy for Poor Rural People using Green Technology. Conference Booklet. Second International Agarwood Conference and Workshop. Bangkok and Koh Chang, Thailand. 4-11 March,2007

Blanchette RA, Jurgens1z JA, van Beek HH. 2015. Growing aquilaria and production of agarwood in hill agroecosystems. http://forestpathology.cfans.umn.edu/ pdf/Growing\%20Aquilaria\%20and\%20production\%20of \%20agarwood\%20in\%20hill\%20agro\%20ecosystems.pdf [10 October 2017]

Blevins DP, Proscott CE, Allen HL, Newsome TA. 2005. The 
effects of nutrition and density on growth, foliage biomass, and growth efficiency of high density fire-origin lodgepole pine central British Columbia. Canadian Journal of Forest Reseach 35(12):2851.

Causton DR. 1988. An Introduction to Vegetation Analysis. 1st edition. London: Unwin Hyman.

Everitt BS, Landau S, Leese M, Daniel S. 2011. Cluster Analysis. United Kindom: A John Wiley and Sons Ltd, Publication.

Foth HD.1984. Dasar-dasar Ilmu Tanah. Yogyakarta: Gadjah Mada University Press.

Ge S, Xu H, Ji M, Jiang Y. 2013. Characteristic of soil organic carbon, total nitrogen and $\mathrm{C} / \mathrm{N}$ ratio in Chinese Apple Orchards. Open Journal of Soil Science 3:213-217. http://dx.doi.org/10.4236/ojss.2013.35025.

Hardiwinoto S. 2015. Peran Silvikultur dalam Peningkatan Produktivitas Hutan dan Rehabilitasi Lahan. Pidato Pengukuhan Guru Besar. Yogyakarta: Universitas Gadjah Mada.

Hadi S, Muliasari H, Sukma NS, Eka P, Ratnaningsih W. 2011. Phytochemical screening and antibacterial testing of agarwood trees (Gyrinops versteegii (Gilg) Domke ) from Lombok Island. 2011:19413.

Hart JW. 1988. Light and Plant Growth. 1st edition. Balk M, Chapman J, editors. London: UNWIM HYMAN Ltd.

Heyne. 1950. Tumbuhan Berguna Indonesia. Terjemahan oleh Badan Litbang Kehutanan Jakarta. Diedarkan oleh Koperasi Karyawan Departemen Kehutanan. Gedug Manggala Wana Bakti Blok I, Jalan Gatot Subroto, Jakarta Pusat. Indonesia

Harper JL. 1983. Population Biology of Plants. New York: Academic Press A Subsidiary Brace Jovanovich. Publisher.

IBM Coorperation. 2013. IBM SPSS Statistics 22 Brief Guide.

Jiyou WU, Minggao C, Chunying D, Xiaofel H, Mingjun H, Yong C, Qiu L, Qijun WUW. 2015. Effect of Land Cover on Soil Temperature, Humidity and Moisture in Phoebe bournei Forest. Agricultural Science \& Technology 18:510 .

Johnson PE. 1014. Beta: Standardized Variable in Regression. Center for Method Data Analysis. Kansas: University of Kansas.

Jones JB, Jr. 2012. Plant Nutrition and Soil Fertility Manual. New York, London: CRC Press Taylor and Francis Group Retrieved.

Killham K. 2001. Soil Ecology. United Kingdom: Cambridge University Press.

Kusmana C. 1997. Metode Survey Vegetasi. Bogor: PT.
Penerbit Institut Pertanian Bogor.

Orloci L, Kenkel NC. 1987. Data Analysis in Population and Community Ecology.

Ludwig JA, Reynold JF. 1988. Statistical ecology a primer on methods and computing. New York: John Wiley \& Sons

Lutz JA, Larson A, Swanson ME, James AF. 2012. Ecological importance of large-diameter trees in a temperate mixedconifer forest. Plos One 7(5):e36131.

Mega IM, Suanda DK, Kasniari DN, Suena W, Parwata MAO. 2012. Formulasi inokulan jamur pembentuk gubal agarwood pada tanaman ketimunan (Gyrinops versteegii) 1. Agrotrop 2(2):139-144.

Mesic M, Birkas M, Zgorelec Z, Kisic I, Juristic A, Sestak I. 2012. Carbon content and $\mathrm{C} / \mathrm{N}$ ratio in Pannonian and Mediterranean Soils. University of Zagreb, Croatia https://bib.irb.hr/datoteka/570357.4._45-54.pdf. [7 October 2017].

Mohamed R. 2016. Agarwood Science Behind The Fragrance. edited by Rozi Mohamed. Singapore: Springer Science+Business Media Singapore 2016 Retrieved (http://www.springer.com/series/5439).

Mori A, Takeda H. 2003. Light-related competitive effects of overstory trees on the understory conifer saplings in a subalpine forest. Journal of Forest Research 8:163-168.

Pet Raija-liisa. 2012. Needle Damage Development in Norway Spruce Seedlings as Affected by Humidity, Temperature , and Gray Mold: A Preliminary Study. 2012(set 1):1-9.

Qamar-uz-Zaman, Schumann AW. 2006. Nutrient management zones for citrus based on variation in soil properties and tree performance. Precision Agriculture (2006):745-763.

Ratri ME. 2013. Ekspor Agarwood Loyo. www.Tribunnews.com/bisnis/2013/09/11/eksporagarwood-loyo. [7 October 2017].

Rawlings JO, Dickey DA, Pantula S. 1989. Applied Regression Analysis? A Research Tool, Second Edition Springer Texts in Statistics. Edition 2nd. Casella G, Fienberg S, Olkin I, editors. New York: Springer Berlin.

Shipley B. 2004. Cause and Correlation in Biology A User's Guide to Path Analysis, Structural Equations and Causal Inference. 1 st editi. USA: cambridge university press The Edinburgh Building, Cambridge CB2 2RU, UK 40 West $20^{\text {th }}$ Street, New York, NY 10011-4211, USA.

Soenarno, Komang S. 2011. Plantation of Eaglewood (Gyrinops versteegii (Gilg.) Domke ) with Interrcopping System, at Rarung, West Nusa Tenggara Province. Jurnal Bulletin Hutan dan Konservasi Alam 8 (4):349-361.

Susilo A, Kalima T, Santoso E. 2014. Panduan Lapangan 
Pengenalan Jenis Pohon Penghasil Agarwood Gyrinops spp. di Indonesia. Susilo A, Kalima T, Santoso E, editor. Indonesia: Pusat Penelitian dan Pengembangan Konservasi dan Rehabilitasi International Tropical Timber Organization (ITTO) - CITES Phase II Project.

Trimulyaningsih, Yamada I. 2008. Notes on Some Species of Agarwood in Nusa Tenggara, Celebes and West Papua.

Trimulyaningsih. 2014. Ekologi agarwood Gyrinops versteegii (Gilg.) Domke di hutan Lombok Barat. [dissertation]. Yogyakarta: Universitas Gadjah Mada.

Turjaman M, Purwito D, Prihadi N. 2015. Indonesia Cites Management and Scientific Authority Indonesia Agarwood. www. Itto.int/files/user/cites/outputs/ indonesia.pdf. [7 October 2017].

Turjaman M. 2011. Proceeding of Agarwood Workshop Production of Agarwood Production Technology A Forest Community Based Empowerment. Turjaman M, editor. Bogor, Indonesia: Indonesia's

Turjaman M. 2011. Proceeding of Agarwood of Development of Agarwood Production Technology. Indonesia: Ministry of Forestry of Indonesia in Cooperation with International Tropical Timber Organization.

Vajari KA, Jalilivand H, Pourmajidian MR, Espahbodi K,
Moshki A. 2012. Effect of canopy gap size and ecological factors on species diversity and beech seedlings in managed beech stands in Hyrcanian forests. Journal of Forestry Research (2012) 23:217-222 https://doi.org/10.1007/s11676-012-0244-6.

Wheater, Philip C, Bell JB, Penny C. 2011. Practical Field Ecology. United Kindom. Wiley-BlackWell. A John Wiley \& Sons, Ltd.

Xiu-ru, Zhang, Xiang-feng T,Ren-qing W, Nan-nan X, Weihua G. 2013. Effects of soil moisture and light intensity on ecophysiological charac- teristics of Amorpha fruticosa seedlings. Journal of Forestry Researc 24:293. https://doi.org/10.1007/s11676-013-0352-y.

Wheater, Philip C, Bell JB, Penny C. 2011. Practical Field Ecology. 1st edition. United Kindom: Wiley-BlackWell, A John Wiley \& Sons, Ltd.

Xiu-ru, Zhang, Tan Xiang-feng, Wang Ren-qing, Xu Nan-nan, and Guo Wei-hua. 2013. Effects of soil moisture and light intensity on ecophysiological charac- teristics of Amorpha fruticosa seedlings. 24 .

Yamani Ahmad. 2010. Analisis kadar hara makro dalam tanah pada tanaman agroforestry di Desa Tambun Raya, Kalimantan Selatan. Jurnal Hutan Tropis 11(30):37-46. 